\title{
Teatro e autoritarismo: as bases coloniais da censura e o Conservatório Dramático Brasileiro
}

\section{Theater and authoritarianism: the colonial bases of censorship and the Brazilian Drama Conservatory}

Gessé Almeida Araújo ${ }^{1}$ 


\section{Resumo}

O artigo traça um panorama histórico-crítico do autoritarismo frente à produção teatral no Brasil, manifestado pelos órgãos de censura. A partir da noção política de "silenciamento" (Orlandi, 2007), o texto evoca as origens coloniais do autoritarismo censório, desembocando na criação do Conservatório Dramático Brasileiro (Rio de Janeiro, 1843). Esta controversa entidade foi a primeira no país oficialmente encarregada pela censura saneadora das produções dos autores de teatro. $\mathrm{O}$ artigo evidencia como a herança autoritária portuguesa, aclimatada em nosso território, influiu sobre as criações no campo das Artes do Espetáculo no Brasil.

Palavras-chave: Artes do espetáculo; autoritarismo; censura; liberdade de expressão

\section{Abstract}

The article makes a historical-critical panorama of authoritarianism in relation to theatrical production in Brazil, practiced by censorship agencies. From the political notion of "silencing" (Orlandi, 2007), this essay evokes the colonial origins of censorial authoritarianism, leading to the creation of the Brazilian Drama Conservatory (Rio de Janeiro, 1843). This controversial entity was the firstone, in the country, to be officially charged with the sanctioning censorship of the productions of the theater authors. The article highlights how the Portuguese authoritarian heritage, acclimatized in our territory, influenced uponthe creations in the field of the Arts of the Show in Brazil.

Keywords: Performing arts; authoritarianism; censorship; freedom of expression 
A reflexão em torno das bases do autoritarismo frente às artes no Brasil exige um inicial entendimento acerca dos mecanismos de silenciamento, noção cujo sentido aqui empreendido considera os estudos da ensaísta Eni Puccinelli Orlandi (2007). Como sugere a referida autora, esta força coercitiva em prol da afasia, inúmeras vezes, atua de modo inesperadamente não-intencional, e a sua ocupação não se dá unicamente no campo das artes, muito menos apenas no campo das palavras. A necessidade de silenciamento censório é própria dos humanos e se estabelece no corpo social de excessivas formas e com a colaboração de diversas instituições sociais a partir de seus artifícios de adestramento comportamental, moral e muitas vezes, afetivo. Como sugere Orlandi (2007), os mecanismos de silenciamento surgem "onde está a linguagem, onde estão as palavras, onde está a significação", ou seja, "estão onde estão os sujeitos e os sentidos, e mudam de lugar e transitam com o tempo" (p.165). É importante salientar que aqui evidenciarei os referidos mecanismos que atuam sobre o fazer artístico do teatro, sobretudo no que diz respeito aos aspectos de elaboração dramatúrgica e alguns aspectos referentes aos procedimentos de encenações.

A natureza dos sentidos formulados pelos sujeitos é composta pela necessidade histórica de sua expressão. Desta maneira, "se um sentido é necessário, ele é possível" (Orlandi, 2007, p.152), o que sugere que a formulação dos sentidos pela recepção de determinado público, de determinado período histórico é possível porque são historicamente necessários. Em muitos momentos, mesmo os espetáculos cuja escrita caminhava pelos rumos da linguagem cifrada com fins ideológicos - notadamente no campo da dramaturgia censurada ou proibida -, os sentidos ou a assimilação histórica do que era retratado em cena eram facilmente elaborados pela audiência, o que atesta um grau de cumplicidade de algumas plateias com os artistas que fizeram uso desse mecanismo. Para que a referida elaboração de sentidos seja possível, se faz necessária a formulação daquilo que Orlandi (2007, p. 166) chama de "silêncio necessário", ou seja, aquilo "que é preciso não dizer para dizer". Evidentemente dentro do panorama moral e político do Brasil, especialmente em períodos de afrouxamento democrático, a interdição na criação de certos autores era um fato ${ }^{2}$. A censura atuou de modo continuado desde os princípios de nossa produção cênica, muitas vezes comprometendo o trabalho dos criadores. Deste modo, o "silêncio" como possibilidade estética em obras dramatúrgicas se estabelecia como algo impositivo que, por força das circunstâncias, se fez "necessário" diante de inconstantes panoramas políticos vividos pelo país.

Foi no campo da materialidade da língua que se deu alguns dos mais fortes embates entre artistas e a censura. Embora reverberem de modo contundente na materialidade cênica, o material mais facilmente acessível hoje para uma análise deste fato são registros como: processos de censura prévia, cópia de textos dramáticos com anotações dos censores responsáveis, fotografias, declarações, ofícios e outros documentos de entidades sociais organizadas solicitando ou reclamando a censura, entre outros. Os embates entre censura e a referida materialidade linguística

\footnotetext{
${ }^{2}$ Refiro-me à estratégia de muitos espetáculos teatrais no Brasil, especialmente durante os regimes políticos autoritários, de utilizar a metáfora como ferramenta que possibilitava o "dizer" para "não dizer". Muitas vezes, dramas históricos ou a dramatização de situações comuns funcionavam como metáfora para a interpretação dos limites de liberdade impostos por diferentes regimes políticos.
} 
dramatúrgica se deram por seu entendimento enquanto campo de "manifestação das relações de força e de sentidos que refletem os confrontos de natureza ideológica" (Orlandi, 2007, p.174-175).

\section{As bases coloniais}

As bases que possibilitaram que o poder autoritário se estabelecesse de modo frutífero na sociedade brasileira possuem forte cunho cultural, em vigor desde os primeiros anos de exploração econômica colonial do Brasil. A "teologia do direito natural objetivo" ou simplesmente a "cultura senhorial" (Chauí, 2013b, p.226) tem raízes profundas na civilização brasileira, estabelecida desde o modelo de exploração adotado aqui pelos primeiros bandeirantes. A este elemento acrescente-se a escravidão indígena e africana como fortes marcadores dos alicerces autoritários com os quais convivemos e nos habituamos. Como princípio segregador, "a sociedade brasileira é marcada pela estrutura hierárquica do espaço social que determina a forma de uma sociedade verticalizada" (Chauí, 2013b, p.226). A verticalização manifestada no espaço social extrapola seus limites e reverbera em outros espaços e relações "sociais e intersubjetivas" (p.226). Do mesmo modo se dão as relações de trabalho, familiares e políticas: prevê-se sempre um "superior" que manda, e um "inferior" que obedece (Chauí, 2013b, p.226). Isto se dá pela característica marcante da estrutura social autoritária brasileira alicerçada "a partir de relações privadas, fundadas no mando e obediência e nas relações de favor e tutela" da qual decorre "a recusa tácita (e às vezes implícitas) de operar com os direitos civis" (Chauí, 2013b, p.227).

Por outro lado, há uma tendência de se pensar a sociedade brasileira como não autoritária. Isso se aproxima bastante do mencionado anteriormente acerca das manobras encobertas de uma suposta liberdade que o poder coercitivo e silenciante pode levar a crer. O autoritarismo é mais fortemente associado aos temas do Estado, isto é, da política com legendas, partidos, coalizões etc. No entanto, uma sociedade autoritária é a mãe de todas as formas de autoritarismo político que presenciamos, como sugere a filósofa Marilena Chauí (2013b, p.226).

Além da já mencionada matriz senhorial apontada como traço marcante do autoritarismo brasileiro, podem ser aludidas, também, características como a "indistinção entre o público e o privado" (Chauí, 2013b, p.227) que reforça, sem maiores constrangimentos, a imagem dos homens e mulheres públicos como verdadeiros donos do poder, cuja relação com a população em geral é sempre a de clientela, quando não de favor (Chauí, 2013b). Esta característica pode ser comprovada pelo alçamento ao poder, no decorrer da história do Brasil, de figuras que ganharam notoriedade sustentando posturas e discursos populistas, cujas características caminharam no sentido do que se reflete aqui. Do mesmo modo, a estrutura estamental das sociedades autoritárias, dadas as bases da cultura senhorial, "preza a fidalguia e o privilégio", usando o consumo de bens de alto custo - o luxo - como "instrumento de demarcação da distância social entre as classes" (Chauí, 2013b, p.226). Portanto, essas características constituem partes importantes de uma sociedade permeada de signos de prestígio e de poder, materializados em exclusivismos de acesso a bens e à própria cidadania. 
Destarte, a sociedade brasileira enquanto sociedade autoritária

[...] conheceu a cidadania através de uma figura inédita: o senhor-cidadão, e que conserva a cidadania como privilégio de classe, fazendo-a ser uma concessão regulada e periódica da classe dominante às demais classes sociais, podendo ser-lhes retirada quando os dominantes assim o decidirem (como durante as ditaduras) (Chauí, 2013b, p.262).

A partir de relações pautadas no privilégio e na dependência das classes submetidas ao autoritarismo, é correto afirmar que a violência simbólica manifestada pelas referidas tutelas ou concessões da cidadania (Chauí, 2013b) é parte incrustada no tecido social brasileiro. Do mesmo modo, é possível sinalizar como manifestações do autoritarismo no Brasil as inúmeras formas que a censura estabeleceu, ora como ingênua benfeitora das diversões públicas, ora como carrasco implacável da produção cultural do país. Como ela compunha parte dos mecanismos que o poder instituído empregava para manter a ordem e se estabelecer, os meios utilizados para este fim são os mesmos que os poderes adotaram a seu favor.

Os mecanismos de censura - não necessariamente contra as artes do espetáculo - que chegaram ao Brasil no período colonial são fortemente marcados pelas características de coerção inquisitorial do final da Idade Média, que perduraram até o Renascimento. Portanto, a censura que inicialmente conhecemos em nosso território tinha como marca profunda a relação com a moral religiosa da igreja católica, com o evidente respaldo da monarquia portuguesa. O aparato censório da igreja, naquele período, ligava-se fortemente à noção de que ao se interditar certas palavras ou ideias que contradiriam a "verdade" estabelecida pelas escrituras sagradas, coibira-se a proliferação do mal profano, mundano, supostamente ligado a forças sobrenaturais malignas (aos moldes do que acontecia na Idade Média). Diante disso, é importante salientar que na Europa, durante parte da Idade Média e do Renascimento, as artes e a vida intelectual, em maior ou menor medida, foram tuteladas - para o bem e para o mal - pelo Estado e pela Igreja Católica.

Em Portugal, durante o período de maior circulação marítima - que coincide com o período de desenvolvimento tecnológico ligado às atividades de impressão -, D. Manuel e D. Sebastião colocaram-se como combatentes da suposta circulação de heresias. Em 1515 e 1571, respectivamente, ambos os reinados passaram a exigir a submissão de obras a um juízo real, antes de serem publicadas, como lembra a pesquisadora Cristina Costa (2010). Explicitamente, este fato se deu por intermédio do tribunal do Santo Ofício, órgão oficial de inquirição de heresias ligado à Igreja romana. O rigor da censura portuguesa demonstrou tamanho fôlego que seus procedimentos foram considerados modelo para a Igreja Católica (Costa, 2010). Eram largamente divulgadas as inúmeras versões do Index Librorum Prohibitorum, no qual constavam os títulos proibidos de circulação, evento este fortemente lembrado como emblema dos atos censórios na Europa. Desde o século XVI foram submetidos à censura não apenas os materiais impressos, mas também as teses produzidas na Universidade de Coimbra, além de sermões religiosos (Costa, 2010; Schwarcz, 2002).

No que diz respeito à presença da interdição nas colônias, Cristina Costa (2010) refere-se ao fato de que a censura portuguesa era mais rigorosa nelas em comparação 
com a metrópole. Esse fato gerou consequências para o desenvolvimento da imprensa e da produção editorial em nossas terras (Costa, 2010), além das influências para a constituição de uma cultura de diversões públicas (onde se inclui o teatro), que a colônia portuguesa da América do Sul só viria a conhecer anos mais tarde. Esses são traços característicos do modelo de colonização portuguesa que em muitos aspectos tentou condicionar os colonos aos desmandos da censura. Os colonizadores portugueses, como ocupantes do poder instituído, souberam manipular os mecanismos de coerção em seu favor. Como exemplo que reforça esse viés de interpretação está o fato de que, diferente da colonização espanhola - que fundou universidades nas colônias desde o século XVI -, Portugal não permitia a criação dessas instituições nos territórios colonizados.

Diante de práticas coercitivas tão presentes no cotidiano, os "espíritos dóceis" conquistados pelos métodos da colonização portuguesa estavam aptos para, em certos momentos, tornarem-se cúmplices do autoritarismo praticado pela censura. Parte dos processos abertos pelas ações de investigação da Inquisição se dava a partir de denúncias espontâneas de conhecidos, que na "ânsia pela delação, ora buscam se aproximar do poder, e ora anseiam demonstrar com essa atitude sua própria inocência" (Costa, 2006, p.29). Esse comportamento de aceitação diante do paternalismo senhorial foi demonstrado em diversos períodos da história da censura no Brasil, de modo que é possível afirmar que os atos de interdição tiveram, em maior ou menor medida, algum nível de adesão popular, no sentido da denúncia de atos considerados desviantes, frente à moral e aos costumes vigentes.

A censura durante o período colonial no Brasil baseava-se numa "metodologia interpretativa" do que se encontrava nas entrelinhas dos discursos, cujas "motivações ocultas e inconscientes" (Costa, 2006, p.29) desejavam desocultar supostas ideias desprimorosas, sobretudo à fé cristã, presentes em obras ou comportamentos. De modo geral, a coerção censória sempre se utilizou de métodos de investigação "questionáveis", tendo no decorrer da história aprimorado seus mecanismos. Bastava a mínima suspeita fragilmente sustentada por uma interpretação tendenciosa ou uma leitura enviesada por parte do censor para que se fizesse valer a "justiça" inquisitorial, cujas penas podiam variar do degredo à morte (Costa, 2006). No esteio do que sugere Costa (2010), é possível afirmar que inúmeras vezes a censura foi usada em favor de "perseguições pessoais de natureza política e econômica", caminho diverso daquele que, ao menos inicialmente, justificou a sua existência: a "defesa da moral e dos bons costumes" (Costa, 2010, p.31).

Além dos já mencionados instrumentos em favor da censura, destaca-se a criação, por parte da Coroa portuguesa durante o reinado de D. Maria I, da Real Mesa Censória em 1768, cuja fundação teve o objetivo de transferir a responsabilidade sobre as atividades ligadas à censura, da Igreja, isto é, da Santa Inquisição para a Coroa (Schwarcz, 2002, p.108). Foi durante a atuação do ministro Marquês de Pombal, que se deu tal evento que acabou por centralizar as ações coercitivas do poder censório em um instrumento estatal que se desejava laico, embora houvesse em sua constituição membros eclesiásticos atuando como funcionários da Coroa portuguesa. Para além da atividade censória, da qual não abriria mão, a Real Mesa Censória portuguesa teve papel de destaque na fiscalização do sistema de educação daquele país, fato este que lhe garantiu o papel próximo ao de um ministério governamental 
(Schwarcz, 2002, p.109). Em outros termos, a partir da atuação desse órgão, estava garantida a censura dos livros que chegassem a Portugal, bem como o controle da difusão das ideias no nível da educação formal. As formas de controle a que tivemos contato inicialmente no Brasil tiveram como matriz esse aparato tecnológico fortemente especializado e eficiente.

Portanto, a censura de cunho político e moralizante, frente à imprensa, a literatura e aos comportamentos, esteve presente na formação do Brasil desde o período colonial. As suas práticas foram baseadas na desconfiança rigorosa, sobretudo contra aqueles que divergissem politicamente dos ideais da Corte além da perseguição a "pessoas de origem desconhecida [...], pobres e mestiços, mulheres sós, gente sem instrução ou família, cristãos novos e ateus" (Costa, 2006, p.34), aos quais é possível acrescentar os sodomitas entre outros "desviados". Estas ações geraram consequências diretas para as instituições brasileiras confirmadas pela sempre presente e necessária negociação com os organismos de poder (Costa, 2006). Ao que consta, desde a nossa concepção enquanto nação, fomos habituados - ou condicionados - a tramitar com o poder instituído numa espécie de diálogo eterno entre o pescoço e a forca. Essa prática entranhada no corpo social brasileiro é a forma com a qual aprendemos a lidar para "conviver com a intolerância e o preconceito endêmicos" (Costa, 2006, p.34). Como consequência desses fatos, convivemos com uma classe dirigente muitas vezes apática aos anseios da população, sobretudo a mais carente, além dos efeitos danosos à arte: a nossa produção nesse campo esteve em muitos momentos de sua trajetória altamente dependente, quando não devotada aos mecanismos de poder institucional.

Inúmeras foram as instituições criadas no Brasil dedicadas à fiscalização pública, ação esta que incluía as atividades ligadas à diversão pública. Dou destaque aqui àquelas que, de modo mais direto, interferiram na dinâmica das produções artísticas, que em nossas terras passou a ter maior relevo após a transferência compulsória da Família Real Portuguesa para o Brasil, em 1808. Foi a partir dessa chegada que a colônia da América do Sul passou a receber, com continuidade, companhias teatrais entre outras atividades culturais. Nesse mesmo período foram criadas a Imprensa e a Biblioteca Nacionais, abriram-se teatros, inclusive o Real Teatro São João em 1812 na cidade de Salvador e, em 1813, no Rio de Janeiro, ambos homônimos.

No que tange aos organismos de vigilância social e censura, meses após a chegada da Família Real foi criada a Intendência-geral de Polícia da Corte e do Estado do Brasil, sobre a qual ficava a guarda da fiscalização dos teatros e das diversões públicas (Costa, 2010). Em decorrência da referida Intendência, foram criadas a Secretaria de Polícia (1808), além da Divisão Militar da Guarda Real de Polícia, todas voltadas às ações de segurança pública de acordo com as novas necessidades da corte, cujo aumento exponencial da população, bem como a presença de Dom João VI e sua família, exigiram. Uma contradição evidente tomou relevo quando da promulgação por D. Pedro I da Constituição Federal de 1824, dois anos após a Independência do Brasil. A Carta Magna então aprovada, curiosamente "assegurava a ampla liberdade de pensamento e expressão, isenta de qualquer censura, mas sujeita, em casos de excessos, a preceitos legais definidos" (Khéde, 1981, p.55). O que se viu na prática foi a censura ganhar espaço, embora submetida à Intendência geral de polícia (Khéde, 1981). 


\section{O Conservatório Dramático Brasileiro}

A partir de 1839, sugeriu-se a criação de uma comissão de censura especializada, sacramentada pelo Estado. Tratava-se da célula inicial do que posteriormente ficou conhecido como Conservatório Dramático Brasileiro. Neste período, a produção teatral no Brasil havia conquistado um espaço importante como prática de sociabilidade. Era crescente o número de produções de companhias brasileiras bem como o número de companhias estrangeiras que por aqui circulavam. Durante praticamente todo o século XIX, o teatro tornou-se uma espécie de ágora na qual a população, principalmente a mais rica, usufruía da vida social. Diante da notoriedade do teatro como centro de lazer deu-se a necessidade da criação, em 1843, do Conservatório Dramático Brasileiro ${ }^{3}$, na cidade do Rio de Janeiro, cuja ação censória atingiu as atividades teatrais de modo sistemático. A sua regulamentação se deu dois anos após, com a promulgação do decreto número 425, de 19 de julho de 1845, data a partir da qual se oficializou sua existência, embora sua atuação já fosse conhecida. Foi a partir do desempenho desse órgão governamental que a censura se estabeleceu como presença marcante no cotidiano dos artistas de teatro, interferindo diretamente nos rumos que ele tomaria. Foi o referido órgão, ainda, que forjou as bases que sustentariam a atuação da censura no Brasil durante todo o período em que ela esteve como presença no cotidiano criador. É verdade que antes da criação da referida instituição, a censura teatral já era praticada de modo pouco metódico sob custódia da já mencionada Intendência-geral de Polícia da Corte e do Estado do Brasil. Assim, o Conservatório Dramático Brasileiro compunha, à época, parte de um conjunto articulado econômica, política e socialmente, que garantiu a sua existência (Khéde, 1981, p.16). Em outros termos, as bases morais e religiosas que sustentariam a atuação do recém-criado organismo já haviam sido criadas, sendo que o Conservatório viria a corroborar o anseio pela criação de um instrumento capaz de fazer o teatro caminhar de acordo com o que se esperava de grandiosas obras de arte, dentro de um padrão de bom gosto e de modernidade que agradasse, sobretudo, ao espírito das classes mais abonadas financeiramente.

Os Artigos Orgânicos da Associação do Conservatório Dramático Brasileiro, primaz do Brasil, estabelecido em 1843 no Rio de Janeiro, inferem como princípio e fim de existência do órgão "animar e excitar o talento nacional para os assumptos dramáticos e para as artes accessorias", além de "corrigir os vícios da scena brasileira, quanto caiba na sua alçada - interpor o seu juízo sobre as obras, quer de invenção nacional, quer estrangeira, que ou já tenha subido à scena"; e ainda: "dirigir os trabalhos cênicos e chamá-los aos grandes preceitos da Arte, por meio de uma análise discreta, em que se apontem e combatam os defeitos e se indiquem os métodos de os emendar" (apud Khéde, 1981, p.58). A intenção inicial da Associação estava baseada no paternalismo das classes dirigentes, personificado nos intelectuais que atuaram como censores. Embora seja possível verificar a informação anteriormente subscrita no Estatuto da instituição, o Conservatório, ao longo dos anos, acabou por

${ }^{3}$ No decorrer dos anos foram criados os demais Conservatórios Dramáticos em importantes estados brasileiros: 0 de Pernambuco data de 1853/54; 0 da Bahia de 1857; o de São Paulo de 1906. 
assumir um caráter veladamente censório, acima de tudo pela força exercida pela religião católica e pelas autoridades políticas que, supostamente, resguardavam a "decência pública" bem como "a castidade da língua" portuguesa e a sua ortoépia (Khéde, 1981, p.19). Deste modo, a censura teatral no Brasil, desde o seu surgimento como instrumento de coerção gerido pelo poder instituído, caracterizou-se "pela prática policial do controle ideológico" (p.19) do que subiria aos palcos, a despeito de que incipientemente estivesse, supõe-se, imbuída em auxiliar a cena brasileira. Foi justamente o caráter assumidamente policialesco que a afastou das preocupações verdadeiramente estéticas da prática teatral - se é que em algum momento ela esteve em seu favor.

Como um dos grandes intuitos do Conservatório Dramático Brasileiros, é possível destacar sua atuação na blindagem, a partir da defesa do decoro e dos costumes, da imagem da Imperial Família. Em vista disso, as artes, em especial o teatro, mantinham relações, até certo ponto, de clientelismo com os organismos do poder, o que lhes garantia barganhar apoio institucional em detrimento da aceitação, muitas vezes pacífica, de uma rotina de coerção que a censura pautava. Deste modo, "aproximar-se do poder e aceitá-lo de forma inconteste passou a ser a salvaguarda para as benesses que ele monopolizava" (Costa, 2010, p.60) e dessa maneira, garantia-se a tutela governamental, cuja pena reverberava na falta de autonomia de pensamento. Acerca da relação entre as artes e o Estado, durante o Império, Costa (2010, p. 60) afirma que:

[...] as artes no Império eram fomentadas pelo Estado, desde que dessem visibilidade à monarquia, defendessem suas ideias e refreassem os ideais republicanos, federativos, nativistas ou libertários. As manifestações artísticas desenvolvidas sob essa política faziam da Europa o centro hegemônico do pensamento e da produção estética e do direito à arte, uma questão de classe.

Por seu instinto de sobrevivência artística, o teatro jogou o jogo possível naquele momento: de maneira geral cedeu ao que a monarquia estabelecia. É importante frisar que o espírito da época, forjado pelas classes dominantes, era pouco propício a manifestações de algum espírito rebelde, posto que foram figuras isoladas as que puderam resistir, dentro do possível, à censura e suas imposições. Qorpo Santo ${ }^{4}$, no Rio Grande do Sul e Martins Pena ${ }^{5}$ no Rio de Janeiro são bons exemplos de resistências possíveis frente à censura durante o século XIX.

A atuação de intelectuais como censores do Conservatório Dramático Brasileiro era vista como mais uma forma de legitimação da ação desejada pela referida instituição. No sentido inverso, esse fato representava para alguns censores uma função que lhes conferia certo status. É o que consta, por exemplo, a respeito do intelectual e artista de teatro, censor do Conservatório Dramático Brasileiro, Martins Pena, um

\footnotetext{
${ }^{4}$ José Joaquim de Campos Leão, mais conhecido pelo pseudônimo Qorpo-Santo (1829 - 1883) foi um dramaturgo, poeta e escritor gaúcho do século XIX. Teve sua obra mais detidamente divulgada e estudada a partir dos anos de 1950 do século XX. Escreveu parte de suas peças sob efeito de crises psicóticas, fato pelo qual foi considerado louco em sua época, além de ter a qualidade de sua produção questionada. Suas obras apresentam contribuições à produção teatral do século XIX ao apresentar temas, personagens e linguagem pouco explorados até então, caracterizando-se, portanto, por uma escrita provocativa e pouco evidente. A constante censura à sua obra é um tema que ainda está por ser explorado aprofundadamente por pesquisadores das artes do espetáculo no Brasil.

${ }^{5}$ Luís Carlos Martins Pena (1815 - 1848) foi dramaturgo e diplomata, autor de comédias de costumes no Brasil do século XIX. Foi mestre e pioneiro em uma escrita que preconizava a ironia e o humor como ferramentas para retratar a sociedade carioca de sua época e suas instituições. Foi duramente criticado como autor de baixa intensidade intelectual pela suposta falta de qualidade de suas peças. Sofreu diversas sanções da censura de sua época e protagonizou alguns dos embates com os órgãos de coerção de então.
} 
dos fundadores do órgão, do qual se desligou três anos após a fundação, em 1846, numa mostra de sua crítica percepção dos reais mecanismos ali institucionalizados. Martins Pena tornou-se um dos autores mais censurados do século XIX graças à sua verve ácida de crítico da cultura, dos costumes e de combate a valores mantidos pela sociedade da época. Khéde (1981) aponta o aludido dramaturgo como o responsável por demolir, a partir de suas peças, a suposta ética vitoriana altamente em voga durante o Segundo Reinado. Pena viveu, portanto, um dilema ético em sua dupla atuação como membro fundador do Conservatório Dramático e autor de teatro e, por este fato, foi notoriamente conhecido - entre outros- como "censor-censurado" (Khéde, 1981, p.46). Por uma série de fatores, não foi possível a Pena ter o reconhecimento em vida de sua escrita como germe de um gênero de comédia à brasileira de rico conteúdo. Este fato se deu, principalmente, devido à sua relação com a censura que se contrapunha à acidez do conteúdo de suas peças e à leitura dos costumes que ele promoveu. Além de Pena, viveram em maior ou menor medida o mesmo dilema personagens da intelectualidade brasileira do século XIX, membros do Conservatório como Machado de Assis, José de Alencar, Gonçalves de Magalhães, Araújo Porto-Alegre, Visconde de Taunay, Quintino Bocaiúva, entre outros.

Como regras mestras da barganha estabelecida entre as artes e o Estado, estava aquilo que o Império pretendia manter como seu regimento: a suposta "invisibilidade da escravidão" e a "naturalidade da monarquia" (Costa, 2010, p.57). Nesse bojo, as citadas características compunham o regimento da produção artística da época, do mesmo modo que a diretriz dos órgãos de censura à cultura (Costa, 2010), maiormente porque estas eram características com as quais a elite brasileira da época se identificava fortemente e diante das quais sentiam a satisfação de seus anseios ao aproximarem-se de produções artísticas supostamente correlatas ao padrão europeu. Para além das mencionadas características, a elite brasileira do século XIX e seu reiterado preconceito diante da cultura mestiça, legitimaram, de certo modo, a prática da censura no Brasil.

A partir da sustentação assegurada pela elite brasileira do século XIX às ações censórias, estas últimas caminharam para rumos que as afastaram da "norma jurídica", uma vez que, embora estivesse no campo da legalidade, "ela[s] geralmente prevalece[m] sobre o Direito" (Khéde, 1981, p.26). A partir dessa reflexão, torna-se pouco aceitável associar a censura à justiça ou à licitude. Em muitos momentos da sua história no Brasil, ela se tornou na visada de Khéde (1981), "o melhor exemplo da legalidade do arbítrio" (p.27). Portanto, a elite brasileira do século XIX criou as bases para que a censura funcionasse como "aparelho repressivo do Estado", isto é, como "força repressiva" (Khéde, 1981, p.29). No caso evidenciado, houve um alinhamento estratégico entre "aparelho repressivo" e "aparelho ideológico", sem o qual a atuação da censura poderia ser dificultada. Em outros momentos da história do Brasil, ambas as forças se aliaram em benefício da mais forte presença do Estado autoritário na repreensão das diversões públicas, o que não foi um privilégio do século XIX e sua elite.

Nesse ponto é importante refletir acerca do papel e da importância que as artes conquistaram durante o século XIX no Brasil. Este foi o período no qual a nação passou a contar com produção cultural motivada pela presença da família real, que trouxe a reboque toda matriz moralizante da fé católica, fator preponderante para a 
regulação da censura, acompanhado do panorama político-social em questão. Para Khéde (1981, p. 75), na história da censura "o conceito de moral e decência pública sempre foi o mais fluido e subjetivo", levando-a abertamente, em alguns momentos, a assumir o arbítrio como prática regulada, acolhida pelo Estado, pela Igreja e demais instituições. Deste modo, o moralismo atinge o campo da cultura artística tendo como mote a noção de arte ligada à correção, ou ainda o teatro como escola dos bons costumes, ideário do Conservatório Dramático (Khéde, 1981). Em outras palavras, se impunha à arte uma função pedagógica doutrinária da qual ela não poderia se desvencilhar.

Era a partir das lentes da moralidade, especialmente a cristã, que os espectadores do século XIX liam as obras artísticas. Nitidamente o viés da "moral" e da "decência pública", defendidos pelos órgãos de censura, eram os que dizem respeito "à formação ideológica da elite imperial" (Khéde, 1981, p.76). Por outro lado, a moral das ruas e de parte da população, em sua maioria de iletrados, era considerada vulgar, de modo que cabia às classes menos abonadas aceitar os preceitos de "decência pública" estabelecidos pela elite (Khéde, 1981, p.76). Promovendo uma extensão analítica para outros momentos da história da censura às diversões públicas no Brasil, a noção de moral evidenciada, sempre foi aquela que convinha às classes dominantes, sobretudo a política. É importante incluir nesse conjunto a classe eclesiástica, cuja mística legitimava a manutenção do status quo da elite da colônia que, por sua vez, autenticava o ritual censório, afirmando a sua "necessária" existência.

Com o intuito de manter o controle da produção teatral a censura interditou durante o ano de 1845, 245 textos de teatro. Dentre as inúmeras justificativas assumidas, estava o fato de algumas dessas obras terem sido consideradas "defeituosas" do ponto de vista da qualidade literária. Decerto, os possíveis "defeitos" apontados tocavam de algum modo nos limites da moral da cristandade. Dentre as três mais recorrentes formas de censura às obras dramáticas à época, estavam os possíveis ataques as "autoridades instituídas", a "ofensa à moral pública" e o "desrespeito à religião", esta talvez, considerada de maior peso (Khéde, 1981, p.90).

Como exemplo da proximidade entre a censura e a Igreja, é notório o ocorrido com a peça escrita em 1838, Antônio José ou o poeta e a Inquisição, considerada uma das obras fundadoras da dramaturgia no Brasil, de autoria de Gonçalves de MagaIhães. O ano do evento é 1847 e o caso perdura como evento inusitado da censura no Brasil, dado o teor da justificativa do censor José Rufino, que proibiu a representação da obra durante toda a Quaresma por ela, supostamente, conter elementos ofensivos à religião católica (Khéde, 1981). Para além da atuação da censura literária mantida pelo Conservatório Dramático Brasileiro, cabia à Polícia da Corte cumprir as funções de Inspeção dos teatros e a fiscalização do decoro, criadas em 1849 (Costa, 2006, p.50). A esses cargos cabia averiguar o cumprimento das determinações da censura ao texto representado, bem como inspecionar o tom que o espetáculo assumia, além de prezar pela ordem social pública.

Em 1871 foi decretada uma portaria que viria a reforçar os laços entre a censura e o ideal de sociedade desejado pela Corte. A citada portaria obrigava os teatros não-subvencionados a manterem em cartaz peças que versassem "unicamente" sobre a moralidade, a religião e a decência; aos teatros subvencionados, além desta, acrescenta-se o 
"merecimento literário" da obra representada (Costa, 2006, p.50). No bojo de todo este conjunto, está em questão o capital simbólico referente a embates entre religião versus paganismo, povo versus elite, monarquia versus república, intelectual versus vulgar, bom gosto versus mau gosto, nacionalismo versus colonialismo, entre outros.

O que se evidencia, a partir de uma leitura das forças arregimentadas pelo Império, é o forte paternalismo dos organismos de poder diante do teatro. Essa característica tinha o objetivo de forçar ao público da Corte a aceitação de obras consideradas de bom gosto por terem como particularidade a reprodução de modelos experimentados em países europeus. Os modelos artísticos importados agradavam a uma minoria - a elite local -, que viam nesse espelhamento uma forma de "compensação, em nível de fachada, para o estatuto da cultura brasileira" (Khéde, 1981, p.95). Em outros termos, a cópia de modelos de obras dramáticas estrangeiras, de certo modo, nos redimia do fato de sermos um país inexoravelmente híbrido. Este acontecimento tornou-se preponderante a partir do momento em que o teatro realizado na Corte durante o século XIX tomou corpo a ponto de catalisar a política e a arte, "colocando-se como intermediário entre a Coroa e o povo" (Khéde, 1981, p.95). A referida tarefa não se apresentou de modo fácil para o teatro que iniciava o seu processo de maturação bem como o de aclimatação à realidade local. A censura demonstrou pouca sensibilidade ao não perceber que o teatro no Brasil estava em busca dos matizes com os quais iria se comunicar, evidenciando os temas da nação recém estabelecida. Dada a conjuntura, a intelectualidade, incluindo aí os intelectuais-censores, acabaram por, salvo exceções, firmar seu compromisso com o ideal de arte preconizado naquele período, a ponto de reforçarem, como sugere Khéde (1981, p. 95), a tese segundo a qual "o que é bom para o poder também o é para a arte".

O corolário do debate em torno da censura ao teatro durante o século XIX no Brasil é que a institucionalização da repreensão aos espetáculos trouxe consigo o vício de uma relação tutorial entre a produção artística, o Estado e a elite. Esse demonstrou ser um meio poderoso de adestramento da criação subvencionada. A fundação dos referidos instrumentos de fiscalização reforçou a dependência da arte ao poder, além de terem facilitado seu uso para fins político-ideológicos (Costa, 2006). Ao mesmo tempo, via-se o teatro desenvolver-se em termos técnicos e também a floração de grandes nomes da dramaturgia e da interpretação da época, como provas do vigor que a produção dramática conquistou.

Com o decorrer dos anos, o Conservatório Dramático passou a ser visto sob uma perspectiva mais crítica até mesmo entre aqueles que por certo período lhe deu sustentação. É o caso, por exemplo, de Machado de Assis. Em crônica datada do final da década de 1850, o autor reconhece a importância de um Conservatório Dramático como elemento de correção da produção da literatura dramática brasileira, ainda por se realizar à época. A finalidade desta instituição segundo o romancista seria o zelo "moral" e "intelectual"; o primeiro seria o responsável pelas correções "menos decentes" da dramaturgia, e o segundo, decidindo sobre "o mérito literário" (Assis, 2001, p.499). Mantendo-se estes alvos, o Conservatório manteria a sua dignidade enquanto instituição e seria um dos responsáveis pelo aprimoramento da arte dramática. A importância de uma instituição corretiva para o campo da dramaturgia seria tão importante que batalhar pela sua nulidade seria "nulificar o teatro" (Assis, 2001, p.499), afirma o romancista. 
Não obstante a necessidade do Conservatório Dramático para a suposta evolução da dramaturgia nacional, Machado de Assis demonstrou uma discordância em relação às práticas daquela instituição. A ação limitada à prática policialesca de cunho moral pode ser apontada como sendo o principal ponto de divergência entre o romancista e a censura exercida pelo Conservatório. Seria necessário, portanto, um avanço do ponto de vista intelectual, que a policialização da censura estava distante de promover: "Não é esta a missão de um Conservatório Dramático. Antes negar a inteligência, que a limita ao estudo enfadonho das indecências [...]" (Assis, 2001, p.500). As atividades da censura promovidas pela referida instituição deveriam, portanto, fazer vistas, também, aos aspectos literários das obras, que na visada machadiana estavam sendo relegados. O que Machado de Assis (2001) reclama é o aprimoramento da censura e não o seu banimento, uma vez que, para ele, esta seria uma instituição de instrução da escrita dramática.

O aprimoramento da dramaturgia seria a pedra de toque a que o Conservatório Dramático deveria se ater, na visada machadiana. Isso se devia ao caráter pedagógico associado ao teatro, fato pelo qual ele não deveria ser tratado como "uma simples instituição de recreio, mas um corpo de iniciativa nacional e humana" (Assis, 2001, p. 501). Assis critica, desse modo, a própria justificativa de criação de uma instituição que deveria zelar pela arte dramática e que, todavia, cumpria o seu papel sofrivelmente atendo-se basicamente aos aspectos morais das obras analisadas, sem ganhos literários. Assim, o cronista vislumbra um "divórcio" entre o objetivo primordial do Conservatório e o rumo que ele seguiu de fato: "O conservatório comprometeu a dignidade do seu papel [...]" (Assis, 2001, p.501).

Machado de Assis (2001) faz uma distinção entre a produção dramática e a produção teatral, sendo a primeira a responsável pela "evolução" do que subiria em cena, em detrimento da segunda, que estaria comprometida com uma estética popularesca. O cronista não se refere de fato ao teatro que ele critica, entretanto, a sua avaliação da censura do Conservatório Dramático - que se viu impelida a "subscrever as frioleiras mais insensatas que o teatro entendesse qualificar de composição dramática" (Assis, 2001, p.501) - parece ter destinatário certo. Desse modo, segundo a visada do autor de Dom Casmurro, a estética de cunho popular, notadamente a comédia, pouco contribuiria para os anseios de uma intelectualidade que ansiava por uma produção dramatúrgica considerada de alto nível.

As críticas de Machado de Assis, embora advogassem a importância da censura como elemento de contribuição à cultura nacional, foi uma das inúmeras que esta instituição sofreu. Ademais, durante os seus 54 anos de atuação, o Conservatório Dramático Brasileiro passou por momentos de desprestígio dada a incoerência e arbitrariedade de seus pareceres. Houve inúmeras situações nas quais esse fato se deu de modo escancarado, sendo que nas mais polêmicas a referida instituição emitia pareceres favoráveis à representação de peças que - por seu turno - eram invalidados pela Polícia, na figura do Inspetor Teatral. A ação desconexa entre os órgãos fiscalizadores foi, dentre outros fatores, a responsável pelo fechamento momentâneo do Conservatório entre os anos de 1864 e 1871. Após esta data, o órgão manteve suas atividades até o ano de 1897, quando foi definitivamente extinto, transferindo para a polícia a responsabilidade pela censura. 


\title{
Concluindo
}

Ao final do século XIX, a censura demonstrou um grau de racionalidade em sua manifestação, a partir da qual reflete Costa (2006, p. 65-66):

\begin{abstract}
A formação do campo artístico paralelamente - através de instituições específicas, como o Conservatório Dramático Brasileiro - distingue a ação simbólica de outras formas de comportamento e atitudes, evidenciando o reconhecimento da natureza e especificidade da prática artística, bem como do poder de sua ação simbólica. E, se o autoritarismo e a arbitrariedade aproximam a prática censória desse século [XIX] de outras ações inquisitoriais do passado, ela também demonstra certo grau de racionalidade política ao incorporar a arte ao exercício do poder.
\end{abstract}

E foi justamente essa herança que a censura, durante o Império, legou ao período Republicano: a compreensão do teatro como importante instrumento de comunicação com as massas, justificando o controle. Aliado a esse fato, com o fortalecimento da imprensa e das editoras bem como das demais modalidades artísticas além do teatro, fez-se necessário ao Estado ampliar os meios de controle das Diversões Públicas. Foram incorporadas a sua prática a referida racionalidade política no controle da indústria cultural que se constituía no país (Costa, 2006). O século XX evidenciou que o controle das artes, do teatro especialmente, e da cultura em geral, tornou-se "uma questão do Estado republicano" (Carneiro, 2002). Isso tudo dentro de um viés interpretativo que não foi capaz de abandonar o moralismo vigente durante o século anterior, que reverberou na repetição dos mesmos erros da prática censória anterior: arbitrariedade e subjetividade excessiva na sua execução, o que aumentava a fragilidade dos pareceres.

Se durante o Império a censura atuava demonstrando certo amadorismo, com a proclamação da República essa questão tomou um rumo diverso. Ainda que o Conservatório representasse a institucionalização da censura, ela ainda era praticada de modo "pessoal e personalista" (Costa, 2006, p.80). Com o passar dos anos e o amadurecimento dos mecanismos de controle ideológico das artes, ela passou a "refletir uma postura pública e legalizada capaz de representar o consenso da sociedade civil republicana" (Costa, 2006, p.80). Como postulado neste artigo, a história da censura às artes do espetáculo no Brasil amadureceu as suas bases coloniais, tendo em seu exercício continuado - representado pelas atividades do Conservatório Dramático - um de seus auges. Entretanto, é preciso considerar que foi durante a primeira República que a censura aumentou a sua eficácia como prática organizada mantendo algum nível de apoio popular, cuja concepção via a prática censória como mera herança dos tempos do Império. Este é um tema a ser explorado mais detidamente por outros pesquisadores e pesquisadoras interessados em contribuir com a fortuna crítica em torno da história e da historiografia das artes do espetáculo no Brasil. 


\section{Referências}

ASSIS, Machado de. O Conservatório Dramático. In: FARIA, João Roberto. Ideias Teatrais: o século XIX no Brasil. São Paulo: Perspectiva/FAPESP, 2001.

CARNEIRO, Maria Luiza Tucci (org.). Minorias silenciadas: a história da censura no Brasil. São Paulo: EDUSP, Imprensa Oficial do Estado/FAPESP, 2002.

CARNEIRO, Maria Luiza Tucci Carneiro. Livros proibidos, ideias malditas: o Deops e as minorias silenciadas. São Paulo: Estação Liberdade: Arquivo do Estado, SEC, 1997.

CHAUÍ, Marilena. Contra a servidão voluntária. Belo Horizonte: Autêntica Editora; São Paulo: Editora da Fundação Perseu Abramo, 2013a.

CHAUÍ, Marilena. Manifestações ideológicas do autoritarismo brasileiro. Belo Horizonte: Autêntica Editora; São Paulo: Editora da Fundação Perseu Abramo, 2013b.

COSTA, Cristina (org.). Censura, repressão e resistência no teatro brasileiro. São Paulo: Annablume; FAPESP, 2008.

COSTA, Cristina. Censura em cena: teatro e censura no Brasil. São Paulo: EDUSP, Fapesp, Imprensa oficial do Estado de São Paulo, 2006.

COSTA, Cristina. Teatro e censura: Vargas e Salazar. São Paulo: Editora da Universidade de São Paulo; FAPESP, 2010.

KHÉDE, Sonia Salomão. Censores de pincenê e gravata: dois momentos da censura teatral no Brasil. Rio de Janeiro: CODECRI, 1981.

ORLANDI, Eni. As formas do silêncio. Campinas; EDUNICAMP, 1997.

SCHWARCZ, Lilia Moritz. A longa viagem da biblioteca dos reis: do terremoto de Lisboa à Independência do Brasil. São Paulo: Cia. das Letras, 2002.

Recebido em: 18/04/2018

Aprovado em: 28/06/2018 